\author{
Qais Ahmed Al- \\ Maamari $^{1}$ \\ Tamer Alkadash \\ Mujeeb Saif Al-Absy \\ Muskan Nagi \\ Manar Ahmed \\ Abdullah
}

Article info:

Received 03.09.2020

Accepted 09.12.2020

$\mathrm{UDC}-005.6$

DOI - 10.24874/IJQR15.02-15

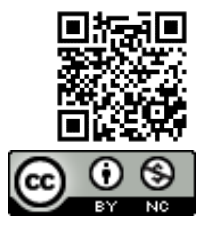

\section{THE MEDIATION IMPACT OF ORGANIZATIONAL COMMITMENTON THE TOTAL QUALITY MANAGEMENT PRACTICES AND INDIVIDUAL READINESS FOR TQM IMPLEMENTATION WITHINYEMENI OIL UNITS}

Abstract: However, there is a huge amount of research on Total Quality Management Practices (TQMps) as a multidimensional construct on individual readiness, there seems to be a lack of literature that provides detailed accounts of procedures for how Total Quality Management Practices (TQMps) have an impact on individual readiness for change (IRFC). This research analyses organizational commitment as a mediator by which total quality management augments individual readiness for change. A survey was conducted on a sample of 360 Yemen Oil Units (YOUs) employees selected using stratified random sampling methods. The data from the self-administered questionnaires, which had a return rate of 60\%, was subjected to Structural Equation Modelling (SEM) analysis and validated that TQMps were the most prominent gauge for individual readiness for change. Furthermore, TQM practices were linked to the rise in Employees' organizational commitment as well as the growth in IRFC. The aim of this research is to further examine the association between TQM practices and the IRFC.

Keywords: Organizational commitment; Total quality management practices; Individual readiness for change; Oil companies; Yemen.

\section{Introduction}

The growing implementation of effective quality assurance systems as management strategies (sometimes known as total quality management or TQM) owes its prominence to the current business climate in which rapid change affects greatly business practice. Stratagems such as these significantly raise organizational efficiency and enhance competitiveness (Attafar, Shahin, \& Kheradmandnia, 2016; Bayazit \& Karpak, 2007; McKay, Kuntz, \& Näswall, 2013, Ruiz et al., 2019). The trials posed by the global economy require multinational as well as single-country organisations to constantly modify themselves and adapt to the dynamic environment in order to remain viable (Choi \& Ruona, 2011; Haffar, Al-Karaghouli, \& Ghoneim, 2014; Sonenshein \& Dholakia, 2012). The information era has generated a highly competitive marketplace worldwide which daunts even the most successful organisations (Fuentes-Henríquez \& Del Sol, 2012; Lawson \& Price, 2003). Be that as it may, numerous studies have showed that a high level of failure is observed during the change implementation stage (Abdolshah \&

${ }^{1}$ Corresponding author: Qais Ahmed Al-Maamari Email: dr.qais.almaamari@gulfuniversity.edu.bh 
Abdolshah, 2011; Choi \& Ruona, 2011; Rashid, Sambasivan, \& Rahman, 2004; Soltani \& Wilkinson, 2010). Individual Readiness for Change (IRFC) has currently become a necessity for bringing about effectual changes in organizations (Armenakis \& Harris, 2002; Clegg \& Walsh, 2004; Holt, Armenakis, Feild, \& Harris, 2007; Jones, Jimmieson, \& Griffiths, 2005; Sikh, 2011; Weeks, Helms, \& Ettkin, 1995). Inadequate knowledge of IRFC disrupts TQM strategy (Meirovich, Galante, \& KanatMaymon, 2006), management of knowledge (Rusly, Corner, \& Sun, 2012) and management of information systems (Jones et al., 2005). Factors that have been perceived to either develop or lessen IRFC in relation to TQM practices (Adil, 2014; Al-Najem, 2014; Ben Jaber, 2010; Ehsein, 2014; Fugate, 2012; Maheshwari \& Vohra, 2015; Naghshbandi, Yousefi, Zardoshtian, \& Moharramzade, 2012; Nordin, 2012; Santhidran, Chandran, \& Borromeo, 2013; Shah \& Shah, 2010; Sloan et al., 2014). As there no empirical reviews on individual readiness for change, as proposed by Haffar, Al-Karaghouli, Irani, Djebarni, and Gbadamosi (2019) that there is a need to find out the relationship between TQMps and IFRC. Although, past research has demonstrated the impact of TQMps on IRFC in developed countries, Arab developing countries tend to be deficient in studies performed. Moreover, even less studies investigate the whole of TQMps and IRFC links. TQM indirectly influences IRFC through organizational commitment. The influence of employees' organizational commitment has been found to significantly affect IRFC with regards to TQM implementation (Al-Abrrow \& Abrishamkar, 2013; Al-Maamari \& Raju, 2020; Anjani \& Dhanapal, 2012; Madsen, Miller, \& John, 2005; Yousef, 2000). Furthermore, research has begun to change its objective to test TQMps' effect on IRFC (Al-Maamari, Abdulrab, Al-Jamrh, \& Al-Harasi, 2017; Haffar et al., 2019; Santhidran et al., 2013; Sloan et al., 2014). Nonetheless, there is a void of research on indirect effects of TQMps on IRFC when mediated by the organizational commitment of employees (Valliappan Raju 2018). This research aims to bridge that void by critically evaluating the interaction of TQMps and IRFC when mediated by organizational commitment. At the time of publishing, this research is the first empirical study of its kind. Also, this study represents the initial of its type that rely on essential and important data from the under examined business practices of Yemen.

The need for TQMps implementation was recognized in Yemen well before the uprising but companies executing TQM are met with various obstacles that hinder the implementation process (Aamer, Al-Awlaqi, \& Alkibsi, 2017; Y Al-Zamany, Dulaimi, Hoddell, \& Savage, 2002; Yasser AlZamany, Hoddell, \& Savage, 2002). Conceptual small-scale studies suggest that most Yemeni companies seek to improve IRFC without proper knowledge of profiting practices and/or without recognizing the level of organizational commitment exhibited by them and their members. Therefore, this research strives to accomplish the following study aims: (1) to examine the impact of TQMps on organizational commitment. (2) To scrutinize the effect of organizational commitment on IRFC with regards to TQM implementation. (3) To examine the mediating role of organizational commitment impact on TQM practices and IRFC. Ultimately, there needs to be a more thorough comprehension of what promotes IRFC with regards to the implementation of TQMps.

\section{Review of literature and development of hypothesis}

\subsection{The effect on TQM practices on Individual Readiness for change}

TQM provides organizations with a clear competitive advantage. Past research has examined the philosophy and implementation of TQM (Ehigie \& McAndrew, 2005). According to Flynn, Schroeder, and Sakakibara (1994), TQMps are the overall 
coordinated efforts towards the accomplishment and continuous maintenance of processes central to the improvement of the company to fulfill and surpass customer expectations. As such, TQM is multidimensional in nature (J. C. Anderson, Rungtusanatham, \& Schroeder, 1994; J. R. Anderson, Reder, \& Simon, 1996; Black \& Porter, 1996; Jayaram, Ahire, \& Dreyfus, 2010). TQM principles permeate from the manufacturing of origin (Flynn et al., 1994), and spreads to the services (Silvestro, 1998), public region (Loomba \& Spencer, 1997) and education sector (Elmuti, Kathawala, \& Manippallil, 1996). Past research has trended towards determining the individual degrees of influence individual components of TQM on IRFC (Al-Maamari, 2020; Al-Maamari et al., 2017; Al-Najem, 2014; Al-Shareem, Yusof, \& Kamal, 2015; Al-Tahitah, Muthaliff, Abdulrab, \& Al-Maamari, 2018; Almaamari et al., 2018; Fugate, 2012; Maheshwari \& Vohra, 2015; Naghshbandi et al., 2012). This burgeoning specialized area of research is due to the ambiguity surrounding TQMps effects on IRFC. It should be emphasized that critical six dimensions of TQM.Thus, the following proposed hypothesis is:

H1. Total quality management practices has positively significant impact on individual readiness for change regarding TQM implementation.

\subsection{The influence of $\mathrm{OC}$ on IRFC}

The commitment level possessed by employees correlates with the efforts put forth by the organization, aimed at garnering these employees' support (Conner, 1993). Herscovitch and Meyer (2002), hold commitment to be among the greatest variables that predict support toward change initiatives among individuals, reflecting a keenness to exert success-oriented behaviours, resulting in it being essential for implementation of change (Herold, Fedor, \& Caldwell, 2007; Porras \& Robertson, 1992). Besides change initiatives are associated with employees' openness to change and their capacity to handle change-resultant stress. (McHugh \& Brennan, 1994; Michela \& Burke, 2000). Employees' Organizational Commitment has been derived as an important element in influencing employees' support towards change (Herscovitch \& Meyer, 2002; Meyer, Srinivas, Lal, \& Topolnytsky, 2007; SEO et al., 2012). Consequently, A comprehensive literature review investigates how the commitment to external success by employees is linked and is one of the internal forces influencing change readiness. Employees' reaction towards the organizational change will lead to either positive or negative effects, which may be serious for the management.

A study done by Madsen et al. (2005) discovered that a positive a significant organizational commitment and readiness for change links. (Anjani \& Dhanapal, 2012; Yousef, 2000), that their findings also supported this result. Al-Abrrow and Abrishamkar (2013), conducted an examination to defined organizational commitment and readiness for change relationship. The author discovered that there is association between organizational commitment and readiness for change. This is consistent with the findings of Iverson (1996), this author determined organizational commitment as a vital antecedent of organizational change. McKay et al. (2013), acknowledged that employees' readiness for change was also revealed to be interrelated to organizational commitment. However, study done by Hallgrímsson (2008), his findings is oppose this, by claiming that employees who show low level of organizational commitment would result in greater readiness for change relative to those who show a high level of organisation, where the outcome is in a discrepancy, whereby their readiness for change will be lower. This is because of the high commitment of the employees to the organization, it is more difficult for those who have a lower degree of commitment to the organisation, to consider changes in the organization. 
Herscovitch and Meyer (2002), consider the three dimensions of change-related support, i.e. normative commitment, continuance commitment, and affective commitment as behavioural outcomes of commitment. According to Azjen (1991), variations precede behavioural responses in the commitment to change attitudinal construct. Accordingly, Herscovitch and Meyer (2002), that demonstrated commitment to change associate positively with IRFC. Positive relationships are found to exist between organizational commitment and change (AlMaamari, 2020; Al-Maamari \& Raju, 2020; Anjani \& Dhanapal, 2012; Nordin, 2011, 2012). Moreover, Meyer and Allen (1991), that argue organizational change can be successful based on the commitment levels of employees, whereby a belief in the intrinsic value of the initiative results in employees wanting to see it succeed. Therefore, based on the discussion thus the association between employee's organizational Commitment, individual readiness for change, the following hypothesis is proposed:

H2. Employees' organizational commitment has significantly a positively impact on individual readiness for TQM implementation.

\subsection{The effect of total quality management practices on employees' Organizational Commitment}

Literature also suggested that Critical success factors are linked to employees' organizational commitment. The significant link between CSFs and employees' organizational commitment can be found in (Montes, Jover, \& Fernandez, 2003). The author claimed that the Total quality management practices as a strategy within the organization. According to Paşaoğlu (2015) suggested that Human resources management in the organization could be affected organizational commitment both singly and systematically. Similarly, Chen, Liu, Cheng, and Chiu (2009) emphasized the human resources management enhanced employees behave higher organizational commitments. In fact, (Aladwan, Bhanugopan, \& D'Netto, 2015; Budhwar, Mellahi, \& Hashim, 2010; Guchait \& Cho, 2010; Juhdi, Pa'wan, \& Hansaram, 2013; Shen \& Jiuhua Zhu, 2011), The authors showed that HRM practices also reflect the organizational commitment of employees, which demonstrated that not only do the organisations implement CSFs in order to increase their readiness for change, but that their implementation will reinforce their organizational commitment. Kumar, Choisne, De Grosbois, and Kumar (2009) observed that adoption of QMPs enhance commitment at all levels of the organization. London (2005) found that the levels of commitment and involvement shown by management (both senior and middle management) had an effect on the success of the process. The above studies show that the impact of TQM practices on the organizational commitment of employees varies considerably. In this context, important success factors and previous studies have shown that TQM practices have the greatest effect rather than consistency and standard on affectivity (Valiappan Raju 2019). The strength of the influence of TQM practice on the corporate commitment of employees clearly depends on the industry. In the meantime, the above analyses also clearly revealed that CSFs performed only restricted studies on total quality management practices for organizational change readiness and the corporate commitment of their employees. Therefore, the following hypothesis is suggested based on the examination of and therefore the TQM practices and the organisational commitment of the employee:

H3. Total quality management practices have positively significant impact on Employees' organizational commitment.

\subsection{The mediating role employees' organizational commitment}

Direct-influences appear to account for effects of TQMps on IRFC. Nonetheless, closer examination reveals that there is an 
implicit presumption of the organizational commitment of employees. As a whole, TQMps impacts the organizational commitment, which, in turn, influences IRFC. Therefore, this research proposes the following hypotheses:

H4. Employees' organizational commitment mediates the effect of Total quality management practices on individual readiness for change regarding TQM implementation.

\subsection{The moderating of organizational culture between Total quality management practices and individual readiness for change}

All organizations share certain attitudes, representation, and viewpoint (Schein, 2010) which have varying definitions as per the context these are placed in. Despite this, ideas like values, beliefs, and assumptions are integral to any organizational culture when people involved consider them to be acceptable (Hofstede et al., 2005) Consequently, to date, there is no appropriate definition of culture. The lack of consensus on what constitutes culture stems from the fact that researchers have borrowed cultural concepts from anthropological literature, and subsequently redefining them within the contexts of organizations and businesses (Rashid et al., 2004). Moreover, most definitions of culture have similar concepts (Valliappan Raju Assoc. Prof. Dr. AND Siew Poh Phung 2019).

Based on the referred TQM literature, (Naghshbandi et al., 2012) found that the conducted empirical studies exploring the TQM practices and willingness for TQM accepting relationship revealed that the findings are inconsistent. To resolve this confusing situation and clarify the reasons behind the mixed results, some scholars such as Naghshbandi et al. (2012) suggested that some variables, that might influence readiness for TQM accepting, should be deeply tested and examined in the future research work. For instance, according to (Al-
Swidi, 2012), the revealed TQM was significant predictors of organizational performance along with $\mathrm{OC}$ in any change management initiative and therefore there is the need to develop OC much in advance to the implementation. Moreover, the study by (Alharbi, 2012) has paved way to investigate between total quality management practices and organizational culture as mediator in Arabic countries and some developing countries, and further it recommended to explore the probabilities of other variables in measuring the effectiveness of quality management practices.

In summary, according to scholars, low level readiness displayed by the individuals lead to failures of change management (Meirovich et al., 2006). In addition, there has not been much of empirical studies examining the impact of some of organizational culture on IRFC (Haffar et al., 2014; Jones et al., 2005). Hence, there are many recommendations to examine the impact of organizational culture (OC) on the association between TQM and individual readiness for change.

\section{Method of Research}

\subsection{The Proposed Research Model}

Holt et al. (2007) is able to assess the readiness for change from four points of view in the conceptual framework for this analysis. It is used to incorporate elements that evaluate the readiness of employees to adjust from two points of view. Figure 1 illustrates the relation of the variables being examined in the research context. The independent variables, which shift from left to right, are TQM practices (change process), employees' organizational commitment (individual attributes), which are a mediating variable and individual readiness to change as a dependent variable.

From the critical previous study, comprehensive investigations and theoretical discussions, we developed a proposed theoretical framework (see Fig. 1). This theoretical framework is derived from 
empirical studies of TQM and individual readiness for change. The model is structured using the organizational change theory, which states that organizational changes are associated with human resource and process issues within a company (McGuire and Hutchings, 2006). TQM can be thought of as change initiative and aims at producing changes in human behaviours within an organization as a high TQM practices level increases individual readiness toward new changes, implementation success, and to describe and study the TQM practices and IRFC links. The framework also draws inspiration from social cognitive theory (Locka, 1987), which proposes that social relationships are sustained on the basis of mutual reciprocity (Blau, 2017), and asserts that these organizational conditions as TQM practices could contribute to the creation of a positive feeling of organizational commitment, which could in turn mediate the relationship between organization conditions (TQM practices) and individual readiness for change, This is to explain and investigate the mediation role of employees' organizational commitment on the association between TQM practices and IRFC regarding TQM implementation. Firstly, the framework suggests that, founded on the social cognitive theory premises, TQM practices are positively related to employees' organizational commitment, and IRFC components. According to these theories, TQM practices effect the cognitive process in which employees' organizational commitment impacts the mutual reciprocity and through that, individuals' readiness to decide whether to resistance or TQM implementation (Shea and Howell, 1998).

This Conceptual framework deviates from present theories that deal with the direct impact of TQMp on IRFC, by highlighting the importance of employees' organizational commitment as a mediator between TQM $\mathrm{p}$ and IRFC in TQM implementation. we developed a proposed theoretical framework (see Fig. 1).

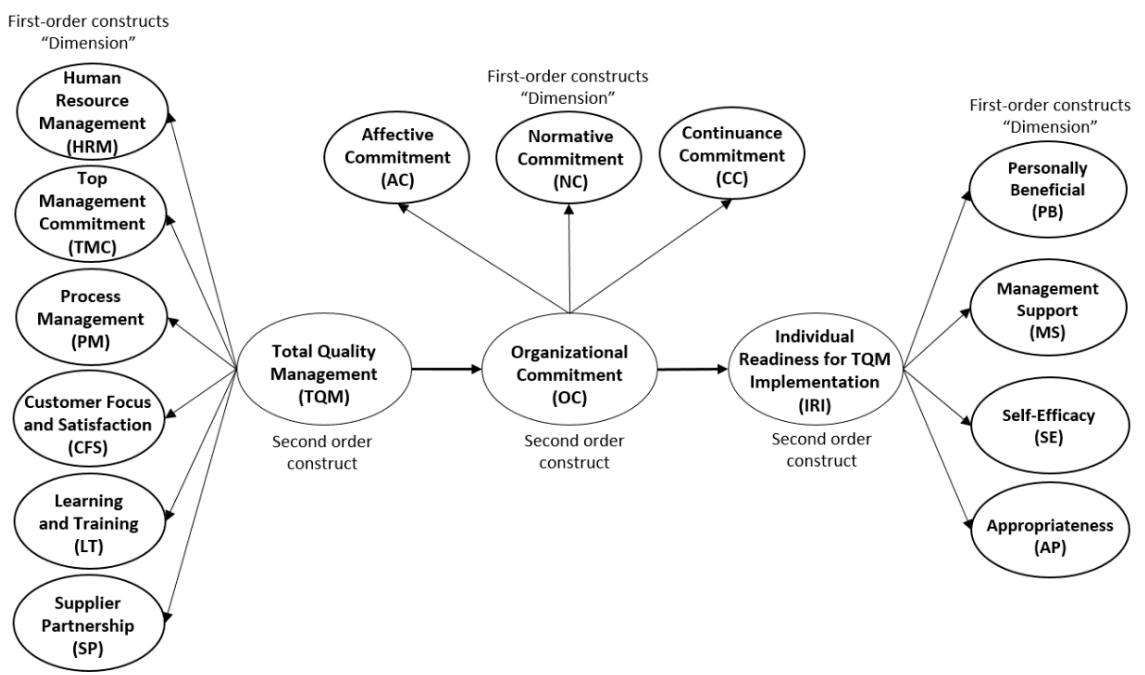

Figure 1. Conceptual Research Framework

\subsection{Development of Instrument}

As the selected sample consisted of Arabspeakers, back translation was utilized to translate three frequently used instruments from English to Arab for the purpose of distribution in Yemen as per prescribed protocol for such cross-cultural surveys. This is done to ensure the accuracy of the translation (Brislin, 1976). This study 
examines the reliability and validity of these scales in terms of context and content validity. The following three constructs were measured.

\subsubsection{Individual readiness for change instrument}

Using the precise instruments developed by Holt et al. (2007), individual readiness for change was measured as a complex single latent variable which in turn was measured by four first-order latent variables. These variables were self-efficacy, personal benefits, management support and appropriateness. The Holt et al. (2007) scale better operationalizes IRFC. The instrument assesses the overall feedback about TQMps in the wider organization by 24 items.

\subsubsection{Employees' organizational commitment instrument}

Organizational commitment was appraised with Herscovitch and Meyer (2002) instrument, developed to assess normative, continuance and affective commitment, and consisted of 18 items. Every item was measured on a 5-point Likert-scale; which is used extensively because it allows sophisticated data analysis (Sekaran and Bougie, 2016).

\subsubsection{Total quality management practices instrument}

TQM factors that are commonplace in industries are analysed, resulting in no significant differences between developed and developing nations; highlighting CSFs' importance in uniform application across differing nations. There exists a strong correlation between TQM practices resulting in synergy (Jayaram et al., 2010). TQM is perceived as a unidimensional set of practices, in this study. Six first-order latent variables measure TQMps, namely HRM (Human Resource Management) using instruments by Lau et al. (2004),TMC(Top management Commitment), that the using instruments by Zhang et al. (2000), PM (Process Management) using instruments by Jayaram et al. (2010), CFS (Customer focus and satisfaction) using instruments by Dow et al. (1999), LT(learning and Training) using instruments developed by Zhang et al. (2000) and finally, SP (supplier partnership) using instruments by $\mathrm{Zu}$ et al. (2010).

A 5-point Linkert-scale ranging between 1 (strongly disagree) and 5 (strongly agree) was used for all of the 18 items as it is an intervaltype scale typically found in organizational research to facilitate advanced data analysis (Sekaran and Bougie, 2013). A pre-test was carried out with participants from four academics and professionals. A revision of the questionnaire took place in Yemen by a group of experts from a local petroleum training centre following which a pilot survey was organised using a convenience sampling technique on 30 full-time employees from three companies that have large population of employees to solve obscurities in terms of wording or measurement. Subsequently, internal consistency was also verified using the pilot-testing method. While the questionnaire has been personally distributed and collected to ensure a 100 percent response rate. They have been asked to respond to the questionnaire. In the actual survey all the items had acceptable reliability, as the alpha coefficients of the buildings of the individual Cronbach were higher than 0,7 recommended (Sekaran and Bougie, 2013, Ramayah, 2011).

\subsection{Data Collection}

The most important element in the sampling is the Yemeni oil and gas sector which includes those Yemen oil companies that are spearheading change initiatives. The North Yemeni city Sana'a houses 11,761 employees of all 10 Oil companies' head offices under study. The data was collected using paper questionnaires that were automatically given individually in order to have a high predictive value, in particular 
when the measurements are related to individual interpretation, conviction and opinion (Yalcinkaya, 2007). Seven hundred questionnaires were issued and 381 sets of which 360 were analytical and considered significant were returned (Tabachnick, 2014, Krejcie and Morgan, 1970). By comparison with previous studies, the response rate was 51 per cent (Baruch and Holtom, 2008). Of the 21 questionnaires that were incomplete, 6 have been excluded for more than 30 percent of questions because of the lack of details.

Table 1 displays the demographic characteristics of the respondents. Firstly,
$6.7 \%$ of the respondents from Ministry of Oil and Minerals (MOM), $22.5 \%$ from petroleum products distribution company (YPC), 1.7\% from Oil and Gas Corporation (YOGC), 6.9\% from Safer Exploration \& Production Operations Company (SEPOC), 29.6\% from Petroleum Exploration and Production Authority (PEPA), 5.0\% from Yemen company for oil refinery (YORC), $2.5 \%$ from Yemen company for petroleum and mineral investment (YICOM), 5.0\% from Yemen Petroleum training center (PTC), 5.8\% from Geological Survey \& Mineral Resource (YGSMRB) and 14.4\% from Yemen gas company (YGC).

Table 1. Demographic profile of respondents Summary

\begin{tabular}{|c|c|c|c|c|}
\hline No & Demographic Item & Categories & Frequency & Percentage \\
\hline 1 & Gender & $\begin{array}{l}\text { 1. Male } \\
\text { 2. Female }\end{array}$ & $\begin{array}{l}254 \\
106\end{array}$ & $\begin{array}{l}70.6 \\
29.4\end{array}$ \\
\hline 2 & Age & $\begin{array}{l}\text { 1. less than } 30 \text { years } \\
\text { 2. } 30-39 \text { years } \\
\text { 3. } 40-49 \text { years } \\
\text { 4. Above } 45\end{array}$ & $\begin{array}{l}50 \\
186 \\
111 \\
13 \\
\end{array}$ & $\begin{array}{l}13.9 \\
51.7 \\
30.8 \\
3.6 \\
\end{array}$ \\
\hline 3 & $\begin{array}{l}\text { Education } \\
\text { background }\end{array}$ & $\begin{array}{l}\text { 1. High school } \\
\text { 2. Diploma } \\
\text { 3. Bachelor } \\
\text { 4. Master } \\
\text { 5. PhD/DBA } \\
\text { 6. Others }\end{array}$ & $\begin{array}{l}26 \\
43 \\
163 \\
114 \\
7 \\
7 \\
\end{array}$ & \begin{tabular}{l|}
7.2 \\
11.9 \\
45.3 \\
31.7 \\
1.9 \\
1.9 \\
\end{tabular} \\
\hline 4 & Positions & $\begin{array}{l}\text { 1. Staff } \\
\text { 2. Head of Department } \\
\text { 3. Department manager } \\
\text { 4. General Manager } \\
\text { 5. Others }\end{array}$ & $\begin{array}{l}139 \\
108 \\
69 \\
15 \\
29 \\
\end{array}$ & $\begin{array}{l}38.6 \\
30.0 \\
19.0 \\
4.2 \\
8.1 \\
\end{array}$ \\
\hline 5 & $\begin{array}{l}\text { Working } \\
\text { experience }\end{array}$ & $\begin{array}{l}\text { 1. below } 2 \text { year } \\
\text { 2. } 2-4 \text { years } \\
\text { 3. } 4-6 \text { years } \\
\text { 4. } 6-8 \text { years } \\
\text { 5. Above } 8\end{array}$ & $\begin{array}{l}8 \\
17 \\
34 \\
51 \\
250 \\
\end{array}$ & $\begin{array}{l}2.2 \\
4.7 \\
9.4 \\
14.2 \\
69.4 \\
\end{array}$ \\
\hline 6 & $\begin{array}{l}\text { Company } \\
\text { name }\end{array}$ & $\begin{array}{l}\text { 1. MOM } \\
\text { 2. YPC } \\
\text { 3. YOGC } \\
\text { 4. SEPOC } \\
\text { 5. PEPA } \\
\text { 6. YORCO } \\
\text { 7. YICOM } \\
\text { 8. PTC } \\
\text { 9. YGSMRB } \\
\text { 10. YGC } \\
\end{array}$ & $\begin{array}{l}24 \\
81 \\
6 \\
25 \\
106 \\
18 \\
9 \\
18 \\
21 \\
52 \\
\end{array}$ & $\begin{array}{l}6.7 \\
22.5 \\
1.7 \\
6.9 \\
29.4 \\
5.0 \\
2.5 \\
5.0 \\
5.8 \\
14.4 \\
\end{array}$ \\
\hline
\end{tabular}


Male were $254(70.6 \%)$ and female 106 (29.4\%). The percentages were less than 30 years old, $51.7 \%$ 30-39 years old, 30.8\% 4049 years old, $3.6 \%$ over 50 years old. $1.9 \%$ had no qualification, and $7.2 \%$ had high school degrees, $11.9 \%$ had diplomas, $45.3 \%$ had Bachelor's (mostly of participants) and the rest $33.6 \%$ had postgraduate degrees completed, $119 \%$ (38.6\%), 108\% (30 percent) were department heads, $69 \%(19 \%)$ were department managers, $15 \%$ (4.2\%) were staff members. In the past they had not earned certificates.

On average, $2.2 \%$ were less than 2 years old, $4.7 \%$ were $2-4$ years old, $9.4 \%$ were between 4 and 6 years old, $14.2 \%$ were between 6 and 8 years old and $69.4 \%$ were above 8 years of age (most participants).

\section{Analysis of data and findings}

\subsection{Analysis of descriptive}

To measure the magnitude and direction of the opinions of the respondents, a 5-point rating scale has been used, and Table 3 reflects mean and standard differences in of research factor. Appropriateness reported the highest mean values of 3.470 out of 5.0, with a standard deviation of 1.129 , suggesting that it is the opinion of the participants that the move will support the organization and meet the company's objectives.

The mean score of self-efficacy was 3,384, with a standard deviation of 1,156 , indicating their confidence that they have the requisite skills, experience and skill. A mean score of 3.328 was recorded for Affective commitment with a standard deviation of 1.110 , indicating that the participants believe in the value of the initiatives, and believe that change is a gainful strategy for the organization.

Mean scores for normative commitment (3.062) with standard deviations of 0.956 , indicate that the respondents feel a sense of duty to work towards this change and are find no cause to resist it. A mean score of 3.187 and a standard deviation of 0.964 was calculated for Supplier Partnership illuminating that the participants agree that long-term relationships are being maintained between the company and suppliers and that the latter also take an active part in the product designing and redesigning processes. Mean scores for customer focus and satisfaction (3.345) with standard deviations of 1.052, Indicate that, as a result of globalization, policy barriers for imported goods have been eliminated and a country's accession to the WTO to promote foreign trade have increased demand over 10 years ago.

\subsection{Measurement Model Assessment and Confirmatory Factor Analysis (CFA)}

As following table clearly illustrates, all good-of-fit indexes have reached their standard acceptance level as found in previous studies, we can therefore conclude that the measuring model is relatively suitable for the data collected $(\mathrm{X} 2 / \mathrm{df}=1.449, \mathrm{CFI}=$ $0.820, \quad$ RMSEA $=0.035, \quad \mathrm{NFI}=0.906$, $\mathrm{TLI}=.965$, IFI $=0.969, \quad \mathrm{PNFI}=0.720$ and PGFI=0.734).

As shown in table 2, the observable model is reasonably good fit. However, as GFI did not suit $(0,843)$, Sharma, Mukherjee, Kumar \& Dillon (2005) dissuaded this index from being used in this context due to its sensitivity, and its failure to be widely used in this context.

The absolute fit indicators show that since the value of the chi square is less than 0.5 , the model is not relevant, however, since the sample is over 200 (Bentler \& Bonett, 1980; Jöreskog \& Sörbom, 1993) and Chi-Square statistics reject the model. The sample size of this survey is 42 and the size of the sample is $>200$ (Byrne 2016). The sample size is 360 . We may therefore test on a construct reliability, indicator reliability, converging validity, and discriminant validity the psychometric properties of a measurement model. 
In order to calculate the reliability of each of the core variables, this analysis evaluated the different Cronbach alpha coefficients in the measuring model. The results show that all the alpha coefficients of individual Cronbach structures ranging from 0.856 to 0.944 were above the required 0.7 (Kannan and Tan, 2005) point. In addition, all $C R$ values ranging from 0.859 to 0.945 were higher than 0.7 for checking construct reliability (Kline, 2015, Gefen et al., 2000), which properly indicate that construct trust is being complied with as shown in table 3. Consequently, the Cronbach Alpha and CR were appropriately error-free for all constructs.

Table 2. Goodness-of-fit indices for the measurement model

\begin{tabular}{|c|c|c|c|c|}
\hline $\begin{array}{c}\text { Fit } \\
\text { Index }\end{array}$ & Cited & Admissibility & Result & Fit (Yes/No) \\
\hline$X^{2}$ & & & 1806.862 & \\
\hline DF & & & 1247 & \\
\hline P value & & $>.05$ & .000 & No \\
\hline $\mathbf{X}^{2} / \mathbf{D F}$ & (Kline, 2015) & $1.00-5.00$ & $\mathbf{1 . 4 4 9}$ & Yes \\
\hline RMSEA & (Steiger, 1990) & $<.08$ & $\mathbf{. 0 3 5}$ & Yes \\
\hline SRMR & (Hu \& Bentler, 1999) & $<.08$ & .033 & Yes \\
\hline GFI & (Jöreskog \& Sörbom, 1993) & $>.90$ & .843 & No \\
\hline AGFI & (Jöreskog \& Sörbom, 1993) & $>.80$ & .820 & Yes \\
\hline NFI & (Bentler \& Bonett, 1980) & $>.80$ & .906 & Yes \\
\hline PNFI & (Bentler \& Bonett, 1980) & $>.05$ & .820 & Yes \\
\hline IFI & (Bollen, 1990) & $>.90$ & .969 & Yes \\
\hline TLI & (Tucker \& Lewis, 1973) & $>.90$ & .965 & Yes \\
\hline CFI & (Byrne, 2016) & $>.90$ & $\mathbf{. 9 6}$ & Yes \\
\hline PGFI & (James, Mulaik, \& Brett, 1982) & $>.50$ & .734 & Yes \\
\hline
\end{tabular}

The reliability of the indicator is calculated with factor loading (Hair et al., 2010, Hair Jr et al., 2016), where higher charging constructs suggest that the indicators have more in common as the construct captured. To be regarded as significant, factor loads must exceed 0.5 (Hair et al., 2010).

Loading for all things was higher than 0,5 as indicated in Table 3 . Thus, all the loading requirements except for items HRM5, HRM5, TMC5, TMC6, PM1, CFS3, CFS4, TL5, TL6, SP5, SP6, AC3, AC5, NC6, CC1, CC5, PB3, PB5, MS3, MS5 SE1, SE 2, AP2, and AP6 have been met, which have been removed due to the low loading speeds.

The convergent value has been evaluated using the derived average variance (AVE), and all values exceeding 0.5 (Hair et al., 2010) varied between 0.604 and 0.810 , that is, exceeded the value recommended. As shown in Table 3, the convergent validity for all constructs has been satisfied and sufficiently converging.

To test the model's discriminant validity, Fornell-Larcker was used to determine (Fornell and Larcker, 1981). The strong relationship between constructs and their respective indicators is shown in the figures in Table 4 which reveals that the association between variables is less than the square base of the average variance, so that good discriminating validity is evident (Hair $\mathrm{Jr}$ et al., 2016). 
Table 3. Mean, standard deviation, loading, cronbach's Alpha, CR and AVE

\begin{tabular}{|c|c|c|c|c|c|c|c|c|}
\hline $\begin{array}{c}\text { Second-order } \\
\text { construct }\end{array}$ & $\begin{array}{c}\text { First-order } \\
\text { constructs }\end{array}$ & Item & $\begin{array}{c}\text { Loading } \\
(>0.5)\end{array}$ & M & SD & $\begin{array}{l}\alpha \\
(>0.7)\end{array}$ & \begin{tabular}{|c|} 
CR \\
$(>0.7)$ \\
\end{tabular} & $\begin{array}{c}\text { AVE } \\
(>0.5) \\
\end{array}$ \\
\hline \multirow{6}{*}{$\begin{array}{c}\text { Total Quality } \\
\text { Management } \\
\text { Practices } \\
\text { (TQM) }\end{array}$} & $\begin{array}{l}\text { Human Resource } \\
\text { Management } \\
\text { (HRM) }\end{array}$ & $\begin{array}{l}\text { HRM1 } \\
\text { HRM2 } \\
\text { HRM3 } \\
\text { HRM4 } \\
\text { HRM5 } \\
\text { HRM6 } \\
\text { HRM7 }\end{array}$ & $\begin{array}{c}0.87 \\
\text { Deleted } \\
0.87 \\
0.88 \\
\text { Deleted } \\
0.86 \\
0.86 \\
\end{array}$ & 3.151 & 1.096 & 0.939 & 0.939 & 0.756 \\
\hline & $\begin{array}{l}\text { Top Management } \\
\text { Commitment } \\
\text { (TMC) }\end{array}$ & $\begin{array}{l}\text { TMC1 } \\
\text { TMC2 } \\
\text { TMC3 } \\
\text { TMC4 } \\
\text { TMC5 } \\
\text { TMC6 } \\
\text { TMC7 } \\
\end{array}$ & $\begin{array}{c}0.85 \\
0.81 \\
0.84 \\
0.79 \\
\text { Deleted } \\
\text { Deleted } \\
0.84 \\
\end{array}$ & 2.908 & 0.925 & 0.916 & 0.916 & 0.685 \\
\hline & $\begin{array}{c}\text { Process } \\
\text { Management } \\
(\mathrm{PM})\end{array}$ & \begin{tabular}{|l|} 
PM1 \\
PM2 \\
PM3 \\
PM4 \\
PM5 \\
\end{tabular} & $\begin{array}{c}\text { Deleted } \\
0.82 \\
0.87 \\
0.88 \\
0.85 \\
\end{array}$ & 2.972 & 0.989 & 0.917 & 0.917 & 0.734 \\
\hline & $\begin{array}{c}\text { Customer Focus } \\
\text { and Satisfaction } \\
\text { (CFS) }\end{array}$ & $\begin{array}{l}\text { CFS1 } \\
\text { CFS2 } \\
\text { CFS3 } \\
\text { CFS4 } \\
\text { CFS5 } \\
\text { CFS6 }\end{array}$ & $\begin{array}{c}0.87 \\
0.87 \\
\text { Deleted } \\
\text { Deleted } \\
0.87 \\
0.83\end{array}$ & 3.345 & 1.052 & 0.920 & 0.920 & 0.743 \\
\hline & $\begin{array}{l}\text { Learning and } \\
\text { Training } \\
\text { (LT) }\end{array}$ & \begin{tabular}{|l} 
TL1 \\
TL2 \\
TL3 \\
TL4 \\
TL5 \\
TL6
\end{tabular} & $\begin{array}{c}0.77 \\
0.86 \\
0.86 \\
0.84 \\
\text { Deleted } \\
\text { Deleted }\end{array}$ & 3.076 & 0.968 & 0.900 & 0.901 & 0.695 \\
\hline & $\begin{array}{l}\text { Supplier } \\
\text { Partnership } \\
\text { (SP) }\end{array}$ & \begin{tabular}{|l} 
SP1 \\
SP2 \\
SP3 \\
SP4 \\
SP5 \\
SP6 \\
\end{tabular} & $\begin{array}{c}0.83 \\
0.85 \\
0.83 \\
0.82 \\
\text { Deleted } \\
\text { Deleted } \\
\end{array}$ & 3.187 & 0.964 & 0.900 & 0.900 & 0.693 \\
\hline \multirow{2}{*}{$\begin{array}{l}\text { Organizational } \\
\text { commitment } \\
\text { (OC) }\end{array}$} & $\begin{array}{l}\text { Affective } \\
\text { commitment } \\
\text { (AC) }\end{array}$ & $\begin{array}{l}\text { AC1 } \\
\text { AC2 } \\
\text { AC3 } \\
\text { AC4 } \\
\text { AC5 } \\
\text { AC6 } \\
\end{array}$ & $\begin{array}{c}0.89 \\
0.87 \\
\text { Deleted } \\
0.91 \\
\text { Deleted } \\
0.86 \\
\end{array}$ & 3.328 & 1.110 & 0.932 & 0.933 & 0.777 \\
\hline & $\begin{array}{l}\text { Normative } \\
\text { commitment } \\
\text { (NC) }\end{array}$ & $\begin{array}{l}\text { NC1 } \\
\text { NC2 } \\
\text { NC3 } \\
\text { NC4 } \\
\text { NC5 } \\
\text { NC6 }\end{array}$ & $\begin{array}{c}0.79 \\
0.84 \\
0.89 \\
0.85 \\
\text { Deleted } \\
\text { Deleted }\end{array}$ & 3.062 & 0.956 & 0.907 & 0.909 & 0.714 \\
\hline
\end{tabular}




\begin{tabular}{|c|c|c|c|c|c|c|c|c|}
\hline & $\begin{array}{l}\text { Continuance } \\
\text { Commitment } \\
\text { (CC) }\end{array}$ & \begin{tabular}{|l|} 
CC1 \\
CC2 \\
CC3 \\
CC4 \\
CC5 \\
CC6 \\
\end{tabular} & $\begin{array}{c}\text { Deleted } \\
0.77 \\
0.79 \\
0.83 \\
\text { Deleted } \\
0.71 \\
\end{array}$ & 2.862 & 0.788 & 0.856 & 0.859 & 0.604 \\
\hline \multirow{4}{*}{$\begin{array}{c}\text { Individual } \\
\text { Readiness for } \\
\text { TQM } \\
\text { Implementation } \\
\text { (IRFR) }\end{array}$} & $\begin{array}{l}\text { Personally } \\
\text { beneficial } \\
\text { (PB) }\end{array}$ & $\begin{array}{l}\text { PB1 } \\
\text { PB2 } \\
\text { PB3 } \\
\text { PB4 } \\
\text { PB5 }\end{array}$ & $\begin{array}{c}0.92 \\
0.92 \\
\text { Deleted } \\
0.89 \\
\text { Deleted }\end{array}$ & 3.066 & 1.001 & 0.933 & 0.934 & 0.825 \\
\hline & $\begin{array}{l}\text { Management } \\
\text { support } \\
\text { (MS) }\end{array}$ & $\begin{array}{l}\text { MS1 } \\
\text { MS2 } \\
\text { MS3 } \\
\text { MS4 } \\
\text { MS5 } \\
\text { MS6 }\end{array}$ & $\begin{array}{c}0.88 \\
0.91 \\
\text { Deleted } \\
0.89 \\
\text { Deleted } \\
0.81\end{array}$ & 2.845 & 0.960 & 0.928 & 0.929 & 0.766 \\
\hline & $\begin{array}{l}\text { Self-Efficacy } \\
\quad \text { (SE) }\end{array}$ & \begin{tabular}{|l|} 
SE1 \\
SE2 \\
SE3 \\
SE4 \\
SE5 \\
SE6 \\
\end{tabular} & $\begin{array}{c}\text { Deleted } \\
\text { Deleted } \\
0.91 \\
0.91 \\
0.89 \\
0.89 \\
\end{array}$ & 3.384 & 1.156 & 0.944 & 0.945 & 0.810 \\
\hline & $\begin{array}{c}\text { Appropriateness } \\
\text { (AP) }\end{array}$ & $\begin{array}{l}\text { AP1 } \\
\text { AP2 } \\
\text { AP3 } \\
\text { AP4 } \\
\text { AP5 } \\
\text { AP6 } \\
\text { AP7 }\end{array}$ & $\begin{array}{c}0.89 \\
\text { Deleted } \\
\text { Deleted } \\
0.89 \\
0.89 \\
\text { Deleted } \\
0.90\end{array}$ & 3.470 & 1.129 & 0.939 & 0.939 & 0.794 \\
\hline
\end{tabular}

Table 4. Results of discriminant validity by Fornell-Larcker criterion for the model

\begin{tabular}{|c|c|c|c|c|c|c|c|c|c|c|c|c|c|c|}
\hline & Factors & 1 & 2 & 3 & 4 & 5 & 6 & 7 & 8 & 9 & 10 & 11 & 12 & 13 \\
\hline & & SE & AC & NC & CC & HRM & TMC & PM & CFS & LT & SP & AP & MS & PB \\
\hline 1 & SE & $\mathbf{0 . 9 0 0}$ & & & & & & & & & & & & \\
\hline 2 & AC & 0.688 & $\mathbf{0 . 8 8 2}$ & & & & & & & & & & & \\
\hline 3 & NC & 0.584 & 0.777 & $\mathbf{0 . 8 4 5}$ & & & & & & & & & & \\
\hline 4 & $\mathbf{C C}$ & 0.523 & 0.687 & 0.735 & $\mathbf{0 . 7 7 7}$ & & & & & & & & & \\
\hline 5 & HRM & 0.662 & 0.519 & 0.408 & 0.354 & $\mathbf{0 . 8 6 9}$ & & & & & & & & \\
\hline 6 & TMC & 0.547 & 0.450 & 0.382 & 0.292 & 0.579 & $\mathbf{0 . 8 2 8}$ & & & & & & & \\
\hline 7 & PM & 0.647 & 0.503 & 0.438 & 0.404 & 0.747 & 0.605 & $\mathbf{0 . 8 5 7}$ & & & & & & \\
\hline 8 & CFS & 0.657 & 0.502 & 0.404 & 0.366 & 0.749 & 0.591 & 0.729 & $\mathbf{0 . 8 6 2}$ & & & & & \\
\hline 9 & LT & 0.638 & 0.517 & 0.456 & 0.403 & 0.744 & 0.574 & 0.749 & 0.760 & $\mathbf{0 . 8 3 4}$ & & & & \\
\hline 10 & SP & 0.643 & 0.483 & 0.448 & 0.359 & 0.737 & 0.628 & 0.752 & 0.775 & 0.770 & $\mathbf{0 . 8 3 3}$ & & & \\
\hline 11 & AP & 0.843 & 0.706 & 0.622 & 0.508 & 0.664 & 0.510 & 0.654 & 0.620 & 0.669 & 0.667 & $\mathbf{0 . 8 9 1}$ & & \\
\hline 12 & $\mathbf{M S}$ & 0.631 & 0.480 & 0.401 & 0.441 & 0.469 & 0.340 & 0.475 & 0.411 & 0.464 & 0.457 & 0.665 & $\mathbf{0 . 8 7 5}$ & \\
\hline 13 & $\mathbf{P B}$ & 0.799 & 0.695 & 0.571 & 0.454 & 0.652 & 0.521 & 0.612 & 0.611 & 0.634 & 0.643 & 0.794 & 0.514 & $\mathbf{0 . 9 0 8}$ \\
\hline
\end{tabular}

\subsection{Structural Model Assessment}

In contrast to the previous CFA model, the structural design was good match, with the values of $\mathrm{X} 2 / \mathrm{df}=1.540, \mathrm{CFI}=0.960$, and
RMSEA $=0.039$. The fit indicator values indicate that the hypothetical model corresponds appropriately to the date observed (Byrne 2016). The track 
coefficients were therefore analyzed in the next step of the structural model.

\subsubsection{Hypotheses Tests}

The hypothesis was tested using structural equation modelling via AMOS and the data obtained is given in Figure 2. The structural model assessment provides the significance of the hypothesis tests in Table 5. Total quality management practices are significantly predicting organizational commitment, hence, $\mathrm{H} 1$ is accepted $(\beta=.72, \mathrm{p} \quad<0.001) . \quad$ Likewise, organizational commitment is significantly predicting individual readiness for TQM implementation, hence, $\mathrm{H} 2$ is accepted $(\beta=.86, \mathrm{p}<0.001)$.

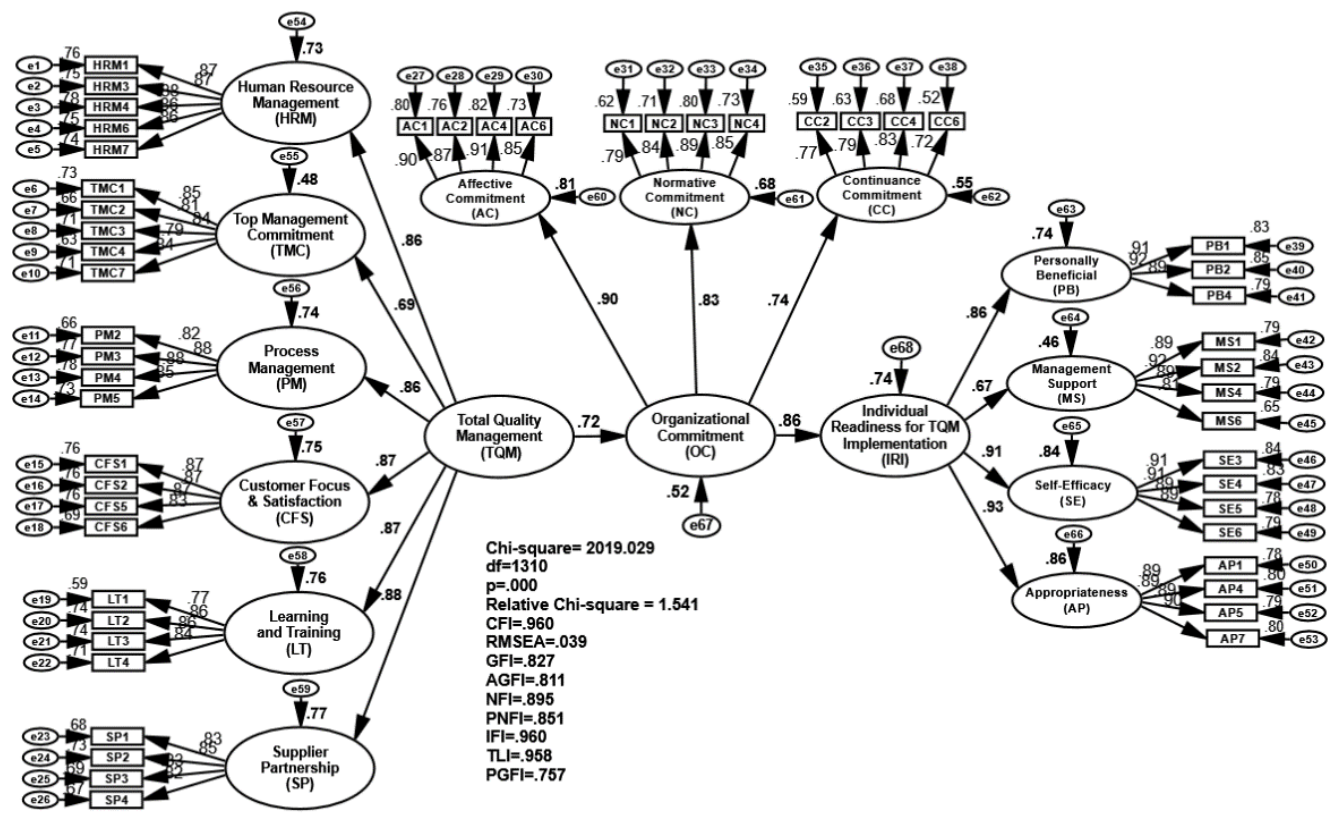

Figure 2. Research structural model results

Table 5. Structural path analysis result

\begin{tabular}{|c|c|c|c|c|c|c|c|c|}
\hline$\#$ & Hypothesis & $\begin{array}{c}\text { Dependent } \\
\text { variables }\end{array}$ & $\begin{array}{c}\text { Independent } \\
\text { variables }\end{array}$ & $\begin{array}{c}\text { Estimate B } \\
\text { (path } \\
\text { coefficient) }\end{array}$ & S.E & $\begin{array}{c}\text { C.R } \\
\text { (t-value) }\end{array}$ & Decision \\
\hline 1 & H1 & OC & $<-$ & TQM & 0.72 & 0.066 & $11.973 * * *$ & Supported \\
\hline 2 & H2 & IRI & $<-$ & OC & 0.86 & 0.049 & $14.394 * * *$ & Supported \\
\hline
\end{tabular}

***p $<.001 ; * * \mathrm{p}<.01 ; * \mathrm{p}<.05$

S.E $=$ Standard Error, C.R = Critical Ratio

Key: TQM: total quality management practices, OC: organizational commitment, IRI: individual readiness for TQM implementation

\subsubsection{Coefficient of Determination $R^{2}$ : the Variance Explained}

The value of $\mathrm{R} 2$ reflects the sum of variation of dependent variables due to the effect of the independent variable; the higher R2 indicates greater predictive capabilities for the structural model. Therefore, in order to obtain the minimum explanation power (Urbach and Ahlemann, 2010), the R2 values must exceed those parameters for the model which Falk and Miller (1992) indicated were equal or 
above 0.10 . The explanation variance was considered acceptable. Cohen (1992) suggested that R2 be above 0.26. Power above 0.02 is appropriate. Wynne (1998) indicated that R2 is significant only when it is more than 0.65 and is over 0.19 appropriate. In comparison, Hair et al. (2013), suggested that R2 be higher than 0.75 to be significant, with a power appropriate above 0.25 . The structural model R2 findings suggest that the dependent variable R2 values (0.74) are adequate for the structural model to achieve appropriate degree of explanatory strength.

\subsubsection{Mediation Assessment}

A structural model must also be examined for the influence of the indirect relationships between latent variables (Henseler et al., 2009). Hence, the mediation hypothesis is tested (H4) as follows:

\section{H4 - organizational commitment mediates the} relationship between TQM practices and individual readiness for TQM implementation.

According to Field (2013), this hypothesis can be substantiated if: (1) TQM practices predict individual readiness for TQM implementation in the first place (path c). (2) TQM practices predict organizational commitment (path a). (3) Organizational commitment predicts individual readiness for TQM implementation (path b). And (4) When organizational commitment is included in a model as opposed to if it is not, relationship between TQM practices and the readiness of the individual to adopt TQM will be smaller.
We can differentiate between the direct effect of TQM practices on individual readiness for TQM implementation, which is the relationship between them controlling for organizational commitment, and the indirect effect, which is the effect of TQM practices on individual readiness for TQM implementation through organizational commitment.

Table 6 indicates direct path results (c) where there is a significant connection between TQM practices and individual readiness to adopt TQM $(\beta=.82, p<0.001)$, this means that the condition of the direct effect is fulfilled. In addition, the path coefficients (a) in this model suggest that TQM practices are positively connected to organisational commitment $(\beta=.72, p<0.001)$, and the path coefficients $(b)$ in this model show that organizational commitment is positively connected to individual readiness for TQM implementation $\quad(\beta=.86, p<0.001)$. Finally, the findings indicate the direct (c') association between TQM practices and individual readiness for TQM implementation $(\beta=.54, p<0.001)$,

Shrink to the inclusion of organizational commitment, but they are still important, suggesting that there is a mediation effect. Although the value of the route coefficient decreased, the value of $\mathrm{R} 2$ for individual readiness for TQM implementation increased from 0.67 (or 67 per cent) to 0.74 (or 74 per cent) when the framework includes organizational commitment.

Table 6. Mediating impact of organizational commitment

\begin{tabular}{|c|c|c|c|c|c|c|c|}
\hline & & & $\begin{array}{c}\text { Estimate B } \\
\text { (path coefficient) }\end{array}$ & S.E & $\begin{array}{c}\text { C.R } \\
\text { (t-value) }\end{array}$ & Result \\
\hline path c & IRI & $<--$ & TQM & .82 & .054 & $13.423^{* * *}$ & Significant \\
\hline path a & OC & $<--$ & TQM & .72 & .066 & $11.975^{* * *}$ & Significant \\
\hline path b & IRI & $<--$ & OC & .86 & .049 & $14.394 * * *$ & Significant \\
\hline path $c^{\prime}$ & IRI & $<--$ & TQM & .54 & .047 & $10.108 * * *$ & Significant \\
\hline
\end{tabular}

Note: TQM: total quality management practices, OC: organizational commitment, IRI: individual readiness for TQM implementation.

$* * * \mathrm{p}<.000 ; * * \mathrm{p}<.01 ; * \mathrm{p}<.05$, S.E = standard Error, C.R = critical Ratio 
The process of bootstrapping the indirect effect is then extended to the mediation effect by Preacher \& Hayes (2008). Table 7 indicates the outcome of the empirical bootstrapping, showing that the $\beta=0.619$ indirect effect with a t-value of 7.460 was important. In addition, Preacher and Hayes (2008) shows that the boot CI of $0.619,95$ percent is not straddling the 0 in between $[\mathrm{LL}=0.397, \mathrm{UL}=0.720]$, which suggests that mediation occurs. Therefore, this analysis should conclude that the mediation impact of the organisation's commitment variable is statistically significant.

Table 7. Bootstrapping the indirect impact of organizational commitment (Preacher \& Hayes 2004, 2008)

\begin{tabular}{|c|c|c|c|c|c|}
\hline Hypothesis & Relationship & Std Beta & Std Error & t-value & Decision \\
\hline H3 & TQM $\rightarrow$ OC $\rightarrow$ IRFC & .619 & 0.083 & $7.460^{* * *}$ & Supported \\
\hline
\end{tabular}

Note: TQM: total quality management practices, OC: organizational commitment, IRFC: individual readiness for TQM implementation.

$* * * \mathrm{p}<0.001$

\section{Discussion and Implications}

\subsection{Discussion}

The results of this study confirmed a critical need to comprehend work- attitude behaviour to improve the quality and efficiency of organizational changes. The analysis of the data collection exposed that employee's organizational commitment has a positive direct influence on IRFC. Depend on theory of social cognitive as discussed in 3.1 , it is employee readiness to accept TQMps. The current findings concur with previous empirical studies on the significance of employee's commitment on success of organizational change implementation (Iverson, 1996) Blau, 1964). Consequently, this existed study acknowledges and understands the complex nature of commitment as given by Herscovitch and Meyer (2002), confirming that affective organizational commitment is a pre-requisite for successful organizational change as suggested by literature (McKay et al., 2013; Nordin, 2011; Yousef, 2000) Nurul Iza, 2014). This research substantiates the arguments of past research (Weeks et al., 1995, Shea and Howell, 1998, Mansor and Zalinawati, 2012, Goksoy, 2012) that fair TQMps creates an openness to change among employees. Furthermore, the relationship between TQM practices and IRFC has partially been mediated by the organizational commitment of employees, indicating that other potential mediating variables in the TQM practices-IRFC link are present.

\subsection{Theortical Implication}

This study added significantly to the body of knowledge on organizational change in the Yemen Oil sector through the inculcation of the current theories, knowledge influencing factors relevant to individual readiness for change in the implementation of TQM (Valliappan Raju and Phung 2020). It has provided a list of factors as composite variable which affecting the individual readiness for implementing TQM within Yemeni Oil companies may be examined. In other hand, from a theoretical perspective, this paper elucidates the three dimensions of employees' organizational commitment and their critical role in increasing individual readiness for change within the Oil context. There are extremely restricted empirical reviews that examine the multidimensional of employees' organizational commitment as composite variable which smoothens the advance of the individual readiness for change level in Yemen.

\subsection{Practical Implication}

Oil companies have been and will remain the cornerstone of the Yemeni economy for a 
long while. Therefore, the findings of this research provide practitioners and policy makers with some strategic 'take-away' implications for enhancing TQM practices and raising the level of IRFC in the implementation of TQM. Firstly, YOUs leaders should build optimistic attitudes towards change-induced TQM for employees. First of all, the top management of YOUs should be aware of the current situation of TQM and therefore be prepared to consider implementation reform measures in psychological terms. Moreover, the leaders of YOUs' must promote employees' participation in implementation of TQM by making a fair incentive system as well as rewarding those who make significant contributions in committing of TQM practices. Employees will therefore form a commitment towards the implementation of TQM. Secondly, YOUs should encourage all stakeholders to participate in decision making and problem solving within the organisation. Furthermore, YOUs' leaders ought to furnish their members with preparing on commitment in the varied TQM practices of implementation, which leads to strengthening feelings of self-efficacy. Consequently, members would help YOUs in accomplish global marketing effectiveness and competitiveness.

\section{Limitations and Suggestions for Future Work}

This review suggests that future reviews utilize longitudinal research design to study possible changes and between the factors of this review over a longer period of time. Besides, future reviews, for-depth interviews with questionnaires may be taken to provide more information on the effect of organizational commitment of employees on the individual readiness for change, thus reducing the bias level. Moreover, the present research constrained to the Yemeni industry organizations and can't be generalized to other area. At last, the present study concentrates on Yemeni Oil Organizations; the attributes of these organizations are socially not the same as those in different nations. Along these lines, this finding ought not to be generalized universally. These outcomes provide strong rules to organizations in other Middle Easterner nations with similar climates as Yemen. It is clear that in past years, much attention has been paid to employee concepts of organizational commitment and readiness to change with respect to TQM implementation and perhaps this will continue. A greater understanding of how the organizational commitment of employees impacts the individual readiness to effectively execute improvements opens up a range of possibilities for employees and organisations. We hope that the study will help to direct future efforts by answering academic and industry concerns.

\section{Conclusion}

The current research contributes to TQM as well as to literature on change management by investigating the media role of the organizational commitment of employees in the relationship between TQM practices and IRFC in the implementation of TQM. In one specific model, IRFC was critically examined for the effects of direct TQM practice on IRFC and indirect effects (through the organizational commitment of employees). Considering the dynamic relationship between TQM activities, the organizational engagement of employees and IRFC helps to foster sound management practices, to maximize the effectiveness of the TQM driven initiative for improvement. The study focused on investigating the relationships among a collection of six TQM variables which can also be influenced by individual readiness for change. Factors such as Top Management Commitment, Human Resource Management, Learning \& Training, Customer Focus \& Satisfaction, Process Management and Supplier Partnership were found to be as composite variable as TQM 
practices influenced individual readiness rates for TQM implementation.

The empirical results showed some of the practices of TQM in Yemeni oil companies, with customer focus \& satisfaction and learning and training being the most commonly followed concepts. The Top management commitment and process management were the lowest values followed. However, data showed IRFC levels in Yemeni oil companies for each of the constructs can be seen from their low mean score $(M<4)$. This does not mean or say that Yemeni oil companies are able to adopt TQM or face no challenges. There remains a death of empirical evidence. Hence, this study would like to draw the reader's attention to the inevitability that failing to consider TQM factors while planning the implementation of change initiatives may lead to lack of support from employees and increase resistance to change. That is why it is crucial that managers recognize the crucial role of the coalesced influence of the aforementioned factors in the success of change initiatives. Conclusively, this research aimed to provide a consistent and detailed view of the relationship between TQM practices and IRFC by assessing and validating the results, whether directly or indirectly.

\section{References:}

Aamer, A. M., Al-Awlaqi, M. A., \& Alkibsi, S. M. (2017). TQM implementation in a least developed country: an exploratory study of Yemen. The TQM Journal.

Abdolshah, M., \& Abdolshah, S. (2011). Barriers to the successful implementation of TQM in Iranian manufacturing organisations. International Journal of Productivity and Quality Management, 7(3), 358-373.

Adil, M. S. (2014). Impact of leader's change-promoting behavior on readiness for change: A mediating role of organizational culture. Journal of Management Sciences, 1(2), 102-123.

Al-Abrrow, H. A., \& Abrishamkar, M. M. (2013). Individual differences as a moderator of the effect of organisational commitment on readiness for change: A study of employees in the higher education sector in Iraq. International Journal of Management, 30(4), 294.

Al-Maamari, Q. A. (2020). The Effect of Total Quality Management (TQM) Practices on Individual Readiness for change with in Yemeni Oil Units. Test Engineering and Management, 83((May - June 2020), 13640 - 13661.

Al-Maamari, Q. A., Abdulrab, M., Al-Jamrh, B. A., \& Al-Harasi, A. H. (2017). The Relationship Between Total Quality Management Practices and Individual Readiness for Change at Petroleum Exploration and Production Authority in Yemen. International Journal of Business and Industrial Marketing, 6(2), 48-55.

Al-Maamari, Q. A., \& Raju, V. (2020). Does Organizational Commitment affect Individual Readiness for Total Quality Management (TQM) Implementation?

Al-Najem, M. (2014). Investigating the factors affecting readiness for lean system adoption within Kuwaiti small and medium-sized manufacturing industries. University of Portsmouth,

Al-Shareem, K. M., Yusof, N. A., \& Kamal, E. M. (2015). External factors influencing the readiness for implementing public-private partnerships among public and private organizations in Yemen. Journal of Science \& Technology Policy Management.

Al-Tahitah, A., Muthaliff, M. M. A., Abdulrab, M., \& Al-Maamari, Q. A. (2018). Paper Review on the Relationship Between Transformational Leadership and Readiness for Change. International Journal of Energy Policy and Management, 3(1), 1-7. 
Al-Zamany, Y., Dulaimi, M., Hoddell, S., \& Savage, B. (2002). The cultural acceptability of the EBEM in Yemen. Managerial Auditing Journal.

Al-Zamany, Y., Hoddell, S. E., \& Savage, B. M. (2002). Understanding the difficulties of implementing quality management in Yemen. The TQM Magazine.

Aladwan, K., Bhanugopan, R., \& D'Netto, B. (2015). The effects of human resource management practices on employees' organisational commitment. International journal of organizational Analysis.

Almaamari, Q., Kassim, R.-N., Raju, V., Al-Tahitah, A., Ameen, A., \& Abdulrab, M. (2018). Factors Affecting Individual Readiness for Change: A Conceptual Framework. 2, 13-18.

Anderson, J. C., Rungtusanatham, M., \& Schroeder, R. G. (1994). A theory of quality management underlying the Deming management method. Academy of management Review, 19(3), 472-509.

Anderson, J. R., Reder, L. M., \& Simon, H. A. (1996). Situated learning and education. Educational researcher, 25(4), 5-11.

Anjani, P., \& Dhanapal, D. (2012). IMPACT OF EMPLOYEE COMMITMENT ON READINESS FOR CHANGE IN BANKING SECTOR IN SALEM DISTRICT. Global Management Review, 6(3).

Armenakis, A. A., \& Harris, S. G. (2002). Crafting a change message to create transformational readiness. Journal of Organizational Change Management.

Attafar, A., Shahin, A., \& Kheradmandnia, M. (2016). The impact of TQM practices on organizational learning case study. International Journal of Quality \& Reliability Management, 33(5), 574-596.

Baruch, Y., \& Holtom, B. C. (2008). Survey response rate levels and trends in organizational research. Human relations, 61(8), 1139-1160.

Azjen, I. (1991). The theory of planned behavior. Organizational behavior and human decision processes, 50(2), 179-211.

Bayazit, O., \& Karpak, B. (2007). An analytical network process-based framework for successful total quality management (TQM): An assessment of Turkish manufacturing industry readiness. International Journal of Production Economics, 105(1), 79-96.

Ben Jaber, A. (2010). Investigating the factors affecting the readiness for TQM implementation within Libyan higher education institutions. Salford: University of Salford,

Bentler, P. M., \& Bonett, D. G. (1980). Significance tests and goodness of fit in the analysis of covariance structures. Psychological bulletin, 88(3), 588.

Black, S. A., \& Porter, L. J. (1996). Identification of the critical factors of TQM. Decision sciences, 27(1), 1-21.

Bollen, K. A. (1990). Overall fit in covariance structure models: Two types of sample size effects. Psychological bulletin, 107(2), 256.

Budhwar, P. S., Mellahi, K., \& Hashim, J. (2010). Human resource management practices on organisational commitment. Personnel Review.

Byrne, B. M. (2016). Structural equation modeling with AMOS: Basic concepts, applications, and programming: Routledge. 
Chen, H.-R., Liu, Y., Cheng, B.-W., \& Chiu, H.-C. (2009). A study of human resource management on organization commitment and organizational citizenship behavior: A comparative case for cross-strait employees of a taiwanese paper company. Journal of the Chinese Institute of Industrial Engineers, 26(4), 289-302.

Choi, M., \& Ruona, W. E. (2011). Individual readiness for organizational change and its implications for human resource and organization development. Human resource development review, 10(1), 46-73.

Clegg, C., \& Walsh, S. (2004). Change management: time for a change! European Journal of Work and Organizational Psychology, 13(2), 217-239.

Conner, D. (1993). Managing at the speed of change: How resilient managers succeed and prosper where others fail: Random House.

Dow, D., Samson, D., \& Ford, S. (1999). Exploding the myth: do all quality management practices contribute to superior quality performance? Production and operations management, $8(1), 1-27$.

Ehigie, B. O., \& McAndrew, E. B. (2005). Innovation, diffusion and adoption of total quality management (TQM). Management Decision.

Ehsein, A. J. (2014). Factors influencing the readiness to adopt performance based budgeting system (pbbs) among Libyan institutions of higher learning. University Malaya,

Elmuti, D., Kathawala, Y., \& Manippallil, M. (1996). Are total quality management programmes in higher education worth the effort? International Journal of Quality \& Reliability Management.

Flynn, B. B., Schroeder, R. G., \& Sakakibara, S. (1994). A framework for quality management research and an associated measurement instrument. Journal of Operations management, 11(4), 339-366.

Fornell, C., \& Larcker, D. F. (1981). Evaluating structural equation models with unobservable variables and measurement error. Journal of marketing research, 18(1), 39-50.

Fuentes-Henríquez, F., \& Del Sol, P. (2012). Analogical foundation of the scope of organizational change. Journal of Organizational Change Management.

Fugate, M. (2012). The impact of leadership, management, and HRM on employee reactions to organizational change. In Research in personnel and human resources management: Emerald Group Publishing Limited.

Goksoy, A. (2012). The impact of Job insecurity, role ambiguity, self monitoring and perceived fairness of previous change on individual readiness for change. Journal of Global Strategic Management, 11(1), 102-111.

Guchait, P., \& Cho, S. (2010). The impact of human resource management practices on intention to leave of employees in the service industry in India: the mediating role of organizational commitment. The International Journal of Human Resource Management, 21(8), 1228-1247.

Haffar, M., Al-Karaghouli, W., \& Ghoneim, A. (2014). An empirical investigation of the influence of organizational culture on individual readiness for change in Syrian manufacturing organizations. Journal of Organizational Change Management.

Haffar, M., Al-Karaghouli, W., Irani, Z., Djebarni, R., \& Gbadamosi, G. (2019). The influence of individual readiness for change dimensions on quality management implementation in Algerian manufacturing organisations. International Journal of Production Economics, 207, 247-260. 
HAIR, J. F., ANDERSON, R. E., BABIN, B. J. \& BLACK, W. C. 2010. Multivariate data analysis: A global perspective, Pearson Upper Saddle River, NJ.

HAIR, J. F., RINGLE, C. M. \& SARSTEDT, M. 2013. Partial least squares structural equation modeling: Rigorous applications, better results and higher acceptance.

HAIR JR, J. F., HULT, G. T. M., RINGLE, C. \& SARSTEDT, M. 2016. A primer on partial least squares structural equation modeling (PLS-SEM), Sage Publications

Hallgrímsson, T. (2008). Organizational change and change readiness: Employees' attitudes during times of proposed merger. Universitetet i Troms $\varnothing$,

Henseler, J., Ringle, C. M., \& Sinkovics, R. R. (2009). The use of partial least squares path modeling in international marketing. In New challenges to international marketing. Emerald Group Publishing Limited.

Herold, D. M., Fedor, D. B., \& Caldwell, S. D. (2007). Beyond change management: A multilevel investigation of contextual and personal influences on employees' commitment to change. Journal of applied psychology, 92(4), 942.

Herscovitch, L., \& Meyer, J. P. (2002). Commitment to organizational change: extension of a three-component model. Journal of applied psychology, 87(3), 474.

Holt, D. T., Armenakis, A. A., Feild, H. S., \& Harris, S. G. (2007). Readiness for organizational change: The systematic development of a scale. The Journal of applied behavioral science, 43(2), 232-255.

Hu, L. t., \& Bentler, P. M. (1999). Cutoff criteria for fit indexes in covariance structure analysis: Conventional criteria versus new alternatives. Structural equation modeling: a multidisciplinary journal, 6(1), 1-55.

Iverson, R. D. (1996). Employee acceptance of organizational change: the role of organizational commitment. International Journal of Human Resource Management, 7(1), 122-149.

James, L. R., Mulaik, S. A., \& Brett, J. (1982). Causal analysis: Models, assumptions, and data. Beverly Hills: Sage.

Jayaram, J., Ahire, S. L., \& Dreyfus, P. (2010). Contingency relationships of firm size, TQM duration, unionization, and industry context on TQM implementation-A focus on total effects. Journal of Operations management, 28(4), 345-356.

Jones, R. A., Jimmieson, N. L., \& Griffiths, A. (2005). The impact of organizational culture and reshaping capabilities on change implementation success: The mediating role of readiness for change. Journal of management studies, 42(2), 361-386.

Jöreskog, K. G., \& Sörbom, D. (1993). LISREL 8: Structural equation modeling with the SIMPLIS command language: Scientific Software International.

Juhdi, N., Pa'wan, F., \& Hansaram, R. M. K. (2013). HR practices and turnover intention: the mediating roles of organizational commitment and organizational engagement in a selected region in Malaysia. The International Journal of Human Resource Management, 24(15), 30023019.

Kline, R. B. (2015). Principles and practice of structural equation modeling: Guilford publications.

Krejcie, R. V., \& Morgan, D. W. (1970). Determining sample size for research activities. Educational and psychological measurement, 30(3), 607-610.

Kumar, V., Choisne, F., De Grosbois, D., \& Kumar, U. (2009). Impact of TQM on company's performance. International journal of quality \& reliability management. 
Lau, R. S. M., Zhao, X., \& Xiao, M. (2004). Assessing quality management in China with MBNQA criteria. International Journal of Quality \& Reliability Management.

Lawson, E., \& Price, C. (2003). The psychology of change management. McKinsey Quarterly, $30-41$

Loomba, A. P., \& Spencer, M. S. (1997). A model for institutionalizing TQM in a state government agency. International Journal of Quality \& Reliability Management.

Madsen, S. R., Miller, D., \& John, C. R. (2005). Readiness for organizational change: do organizational commitment and social relationships in the workplace make a difference? Human Resource Development Quarterly, 16(2), 213-234.

Maheshwari, S., \& Vohra, V. (2015). Identifying critical HR practices impacting employee perception and commitment during organizational change. Journal of Organizational Change Management.

Mansor, N., \& Abdullah, Z. (2011). The Successful Implementation of TQM: In Malaysian Local Authority.

McHugh, M., \& Brennan, S. (1994). Managing the stress of change in the public sector. International Journal of Public Sector Management.

McKay, K., Kuntz, J. R., \& Näswall, K. (2013). The effect of affective commitment, communication and participation on resistance to change: The role of change readiness. New Zealand Journal of Psychology (Online), 42(2), 29.

Meirovich, G., Galante, I., \& Kanat-Maymon, Y. (2006). Attitudes towards TQM and the communication process between managers and subordinates. Journal of Applied Management and Entrepreneurship, 11(1), 74.

Meyer, J. P., \& Allen, N. J. (1991). A three-component conceptualization of organizational commitment. Human resource management review, 1(1), 61-89.

Meyer, J. P., Srinivas, E. S., Lal, J. B., \& Topolnytsky, L. (2007). Employee commitment and support for an organizational change: Test of the three-component model in two cultures. Journal of occupational and organizational psychology, 80(2), 185-211.

Michela, J. L., \& Burke, W. W. (2000). Organizational culture and climate in transformations for quality and innovation. Handbook of organizational culture and climate, 225-244.

Montes, F. J. L., Jover, A. V., \& Fernandez, L. M. M. (2003). Factors affecting the relationship between total quality management and organizational performance. International Journal of Quality \& Reliability Management.

Naghshbandi, S., Yousefi, B., Zardoshtian, S., \& Moharramzade, M. (2012). Assessment of Military Force Staff's Readiness for Total Quality Management (TQM) Approval in Tehran Province. Procedia-Social and Behavioral Sciences, 46, 5345-5349.

Nordin, N. (2011). The influence of emotional intelligence, leadership behaviour and organizational commitment on organizational readiness for change in higher learning institution. Procedia-Social and Behavioral Sciences, 29, 129-138.

Nordin, N. (2012). The influence of leadership behavior and organizational commitment on organizational readiness for change in a higher learning institution. Asia Pacific Education Review, 13(2), 239-249.

Nurul Iza, A. (2014). Trust in management, communication, Islamic work ethics and readiness for change a mediating effect of organisational commitment (Doctoral dissertation, Universiti Utara Malaysia). 
Paşaoğlu, D. (2015). Analysis of the relationship between human resources management practices and organizational commitment from a strategic perspective: Findings from the banking industry. Procedia-Social and Behavioral Sciences, 207, 315-324.

Porras, J. I., \& Robertson, P. J. (1992). Organizational development: Theory, practice, and research: Consulting Psychologists Press.

Preacher, K. J., \& Hayes, A. F. (2008). Asymptotic and resampling strategies for assessing and comparing indirect effects in multiple mediator models. Behavior research methods, 40(3), 879-891.

Ramayah, T. 2011. Notes for data analysis workshop. http://ramayah.com/wpcontent/uploads/2011/04/Data-Analysis.pdf.

Rashid, Z. A., Sambasivan, M., \& Rahman, A. A. (2004). The influence of organizational culture on attitudes toward organizational change. Leadership \& organization development Journal.

Ruiz, E., Sánchez de Pablo, J. D., Muñoz, R. M., \& Peña, I. (2019). Do high performance work systems enhance business performance? Examining the mediating influence of total quality management. Proceedings of Rijeka Faculty of Economics: Journal of Economics and Business, 37(1), 235-258. https://doi.org/10.18045/zbefri.2019.1.235

Rusly, F. H., Corner, J. L., \& Sun, P. (2012). Positioning change readiness in knowledge management research. Journal of Knowledge Management.

Santhidran, S., Chandran, V., \& Borromeo, J. (2013). Enabling organizational changeleadership, commitment to change and the mediating role of change readiness. Journal of business economics and management, 14(2), 348-363.

SEO, M. G., Taylor, M. S., Hill, N. S., Zhang, X., Tesluk, P. E., \& Lorinkova, N. M. (2012). The role of affect and leadership during organizational change. Personnel psychology, 65(1), 121 165.

Shah, N., \& Shah, S. G. S. (2010). Relationships between employee readiness for organisational change, supervisor and peer relations and demography. Journal of Enterprise Information Management.

Shea, C. M., \& Howell, J. M. (1998). Organizational antecedents to the successful implementation of total quality management: a social cognitive perspective. Journal of Quality Management, 3(1), 3-24.

Shen, J., \& Jiuhua Zhu, C. (2011). Effects of socially responsible human resource management on employee organizational commitment. The International Journal of Human Resource Management, 22(15), 3020-3035.

Sikh, G. (2011). Analysis of attitudes and behaviours of employees towards organizational change. International Journal of Human Resource Management and Research, 1(1), 1-13.

Silvestro, R. (1998). The manufacturing TQM and service quality literatures: synergistic or conflicting paradigms? International Journal of Quality \& Reliability Management.

Sloan, T., Fitzgerald, A., Hayes, K. J., Radnor, Z., Robinson, S., Sohal, A., . . Al Hajri, A. (2014). Readiness factors for lean implementation in healthcare settings-a literature review. Journal of health organization and management.

Soltani, E., \& Wilkinson, A. (2010). Stuck in the middle with you: The effects of incongruency of senior and middle managers' orientations on TQM programmes. International Journal of Operations \& Production Management.

Sonenshein, S., \& Dholakia, U. (2012). Explaining employee engagement with strategic change implementation: A meaning-making approach. Organization Science, 23(1), 1-23. 
Steiger, J. H. (1990). Structural model evaluation and modification: An interval estimation approach. Multivariate behavioral research, 25(2), 173-180.

Tabachnick, B. G., Fidell, L. S., \& Ullman, J. B. (2007). Using multivariate statistics (Vol. 5, pp. 481-498). Boston, MA: Pearson.

Tucker, L. R., \& Lewis, C. (1973). A reliability coefficient for maximum likelihood factor analysis. Psychometrika, 38(1), 1-10.

Urbach, N., \& Ahlemann, F. (2010). Structural equation modeling in information systems research using partial least squares. Journal of Information technology theory and application, 11(2), 5-40.

Weeks, B., Helms, M. M., \& Ettkin, L. P. (1995). Is your organization ready for TQM? An assessment methodology. The TQM Magazine.

Yalcinkaya, R. (2007). Police officers' adoption of information technology: A case study of the Turkish POLNET system. University of North Texas.

Yousef, D. A. (2000). Organizational commitment and job satisfaction as predictors of attitudes toward organizational change in a non-western setting. Personnel review.

Zhang, Z., Waszink, A. B., \& Wijngaard, J. (2000). An instrument for measuring TQM implementation for Chinese manufacturing companies. International Journal of Quality \& Reliability Management.

Zu, X., Robbins, T. L., \& Fredendall, L. D. (2010). Mapping the critical links between organizational culture and TQM/Six Sigma practices. International journal of production economics, 123(1), 86-106.

Qais Ahmed Al-Maamari

Gulf University,

Sanad, Kingdom of Bahrain

dr.qais.almaamari@gulfuniversity.edu.bh

\section{Mujeeb Saif Al-Absy}

Gulf University,

Sanad, Kingdom of Bahrain

dr.mujeeb.saif@gulfuniversity.edu.bh

\section{ManarAhmed Abdullah}

University of Sciences and Technology

(USTC), China,

almaamari.moni24@gmail.com

\section{Tamer Alkadash}

Gulf University, Sanad, Kingdom of Bahrain dr.tamer.alkadash@gulfuniversity.edu.bh

\section{Muskan Nagi}

Gulf University,

Sanad, Kingdom of Bahrain

dr.muskan.nagi@gulfuniversity.edu.bh 
